\title{
Review
}

\section{Stem cells of the adult mammalian brain and their niche}

\author{
O. Basak and V. Taylor* \\ Department of Molecular Embryology, Max Planck Institute of Immunobiology, Stubeweg 51, 79108 Freiburg \\ (Germany), Fax: +49 7615108 474, e-mail: taylor@immunbio.mpg.de
}

Received 03 September 2008; received after revision 09 October 2008; accepted 14 October 2008

Online First 18 November 2008

\begin{abstract}
The mammalian brain is a paradox of evolution. Although the advance in complexity of the human brain has exceeded the development of other organs, it has practically lost the ability to regenerate, and damage is repaired mainly by functional plasticity. This disparity is, however, not due to the lack of progenitor cells in the adult mammalian brain, but to their diminished or repressed capacity to
\end{abstract}

replace neurons in most brain regions. Here, we discuss the current literature describing the processes of neurogenesis in the adult mammalian brain, and the recent advances in adult neural stem cells (aNSCs) with a focus on their identity, cell cycle and niche signals. Understanding these processes may hopefully lead to therapies in the future to reinstate self-repair of the brain from endogenous progenitors.

Keywords. Neural stem cells, neurogenesis, stem cell niche, adult brain, subventricular zone.

\section{The discovery of neurogenesis in the adult brain}

NSCs are the foundations of the brain during development, and despite poor regenerative capacity, they persist in the mammalian brain throughout postnatal development and into adulthood and continue to generate neurons. aNSCs self-renew and retain multipotency in almost all mammalian species analyzed, including humans. NSCs reside in specialized germinal layers where multiple cell-types interact with them and contribute to generate niches that control their fate choices and permit neurogenesis. Genetic and functional analyses have revealed roles for several genes and signaling pathways in controlling adult neurogenesis. However, the identities of the stem cells in the brain remain elusive, which presents an elementary problem for the interpretation of these results. In attempts to identify aNSCs, several groups have defined populations that contain cells with stem

* Corresponding author. cell features, although unambiguous markers are still missing. Given their potential as putative tools for cell-based therapies, elucidating the molecular pathways that identify aNSCs and govern their cell fate is essential.

Neurons in most regions of the adult mammalian brain are generated from NSCs and restricted progenitors during embryonic development before a switch to gliogenesis in peri- and postnatal development [1]. As early as the 1960s and 70s, newly generated neurons were identified by nucleotide analogue incorporation assays in adult rodents $[2,3]$. These results, however, met with skepticism due to the poor regenerative capacity of the mammalian brain. Detailed studies went on to show extensive neurogenesis in the vocal control center in the brains of adult canaries, which correlates with seasonal song learning $[4,5]$. After a brief re-visitation to the topic in the mid-1980s, it was the use of retroviral lineage tracing assays that identified newborn neurons in the adult mammalian brain. These findings were quickly followed by the identification of zones with neurogenic capacity in 
multiple mammalian species including humans $[2,3$, 6-9]. Evidence of continued adult neurogenesis intrigued many who long believed that the adult mammalian brain had lost its neurogenic capacity compared to the avian and fish brain, and further provoked questions about the neural progenitors which retain proliferative capacity and are capable of giving-rise to more differentiated progeny including neurons. The phenomenon of NSC as a life-long source of neural progenitors and newly generated neurons in adults was proposed after the isolation of cells that can be propagated for an unlimited amount of time and generate all three lineages of the adult brain in vitro $[6,7,10]$.

\section{Cellular architecture of the neurogenic zones}

Although multiple proliferative zones have now been identified in the adult central nervous system, neurogenesis is most prominent and best studied in two defined germinal centers, the subependymal layer of the lateral ventricle wall covering the striatum (SEZ) and the dentate gyrus of the hippocampal formation. The SEZ is the major source of adult neurogenesis generating at least 5 subtypes of interneuron of the olfactory bulb and, to a limited extent, oligodendrocytes of the corpus callosal white matter [2, 11, 12]. Estimations suggest that 30-60,000 new neurons may be generated per day in the adult rodent olfactory bulb $[13,14]$.

Morphologically, four major cell-types have been identified in the rodent SEZ. SEZ astrocytes are mitotically inactive and can be subdivided depending on chromatin structure $[15,16]$. One undisputed role of the astrocytes is to form "glial tubes" that ensheath migrating neuroblasts, confining them to the rostral migratory stream (RMS) and separating them from the surrounding parenchyma. Neuroblasts are the principal product of the SEZ and migrate in chains to the olfactory bulb where they distribute radially to the granule and glomerular layers before undergoing terminal differentiation. Neuroblasts are generated from resident stem cells in the SEZ through a transient amplifying population (TAPs) $[11,13,15]$. The neurogenic zone is covered by a ventricular lining of mitotically-inactive ependymal cells with motor cilia extending into the ventricle that circulate cerebrospinal fluid generated by the choroids plexus. Evidence indicates that ependymal cell-mediated directed movement of factors, including Slit proteins in the cerebrospinal fluid, determines migration of neuroblasts to the olfactory bulb [17].

Similarly, the human SEZ is divided into four morphologically distinguishable layers with cell-types reminiscent of those found in rodents. Lining the ventricles, layer 1 is composed of ependymal cells extending basal processes into a hypocellular gap (layer 2). Layer 2 contains some neurons and neuronal fibers and occasional astrocytes [18]. Interestingly, neither rodents nor non-human primates have this hypocellular gap which, in addition to humans, has so far only been detected in bovine brains [18-20]. Layer 3 contains a ribbon of astrocytes that extend processes to layer 2 and might make contact with the ependymal cells [18]. Layer 3 contains cells morphologically similar to the TAPs in rodents and has been suggested to contain aNSCs $[18,21]$. The SEZ is delineated from the brain parenchyma by the myelin rich layer 4 [20]. A migratory track reminiscent of the RMS in the other mammals is also present in humans and recent reports claimed to have identified $\beta$-tubulinIII+ (Tuj1) neuroblasts; however, evidence for chain migration is lacking [18, 20, 22].

Neurogenesis in the adult mammalian hippocampus involves similar steps to those of the SEZ, although unlike in the forebrain, the source (subgranule zone SGZ) and target (granule cell layer) of the newborn neurons are juxtaposed [23, 24]. Astrocytes of the SGZ have two basic morphologies. Those with pyramidal cell-bodies and radial processes extending through the granule cell layer towards the surface of the dentate, similar to embryonic radial glia, include a population of stem cells [23, 24]. Recently, a second population of SGZ astrocytes with tangential rather than radial processes has been shown to express progenitor markers and behave like stem cells in vivo [25]. Interestingly, this finding questions the dogma of radial astrocytes as the sole stem cells of the dentate and indicates that tangential cells may make-up the predominant active stem cells of the hippocampus. In addition, retroviral labeling indicates that these nonradial cells undergo asymmetric cell division to generate neurons but can also produce daughters that adopt a radial morphology. As in the SEZ, dentate neurogenesis progresses through transient intermediates and mitotically active neuroblasts before newborn neurons migrate radially into the granule cell layer.

\section{Neural progenitors in the adult brain}

Endogenous NSCs are, according to the definition, capable of self-renewal throughout the life of the organism and multi-lineage differentiation (multipotency) into neurons, astrocytes and oligodendrocytes [26]. However, the exact identity of the aNSCs has yet to be determined. Due to the lack of unambiguous markers, single aNSCs in the adult neurogenic niches 
cannot be identified [7]. As a consequence, marker gene expression, viral and genetic approaches can only be used to label populations of cells that include a variety of cell-types with different antigenic, cell cycle, self-renewal, and differentiation potentials. Thus, these experiments are inevitably a retrospective estimation of cell populations that may contain multipotent or multiple lineage restricted stem cells. For instance, although both neurons and oligodendrocytes are generated in the adult mouse SEZ, there is no evidence that a single cell gives-rise to both lineages in vivo. Furthermore, although strictly speaking the stem cell should maintain self-replicating potential throughout the life of the organism, a more flexible and potentially more tangible scenario is that the stem cells have a limited life span. Thus, active stem cells may become exhausted with time, either resulting in a reduction in progenitors with age, which is observed in both adult neurogenic brain regions, or that the active NSCs are replaced by precursors that, under normal circumstances, do not contribute significantly to active neurogenesis. In reality, neurogenesis may use a combination of both strategies. It will be a central objective in the future to combine genetics and lineage tracing not only to identify the NSCs in the adult brain but also to elucidate the mechanisms that control their maintenance and fate in vivo.

Although it has not been possible to date to identify aNSCs in situ, cells with NSC-like character can be isolated from the adult brain and expanded in vitro using the neurosphere assay. Spherogenic cells selfrenew in vitro in response to epidermal growth factor (EGF) or fibroblast growth factor 2 (FGF2) and clonally generate neurons, astrocytes and oligodendrocytes [6, 7, 27-29]. Spherogenic cells represent prospective NSCs, although the retrospective nature of the method evoked questions about their source and the relationship to the NSCs in vivo. In addition, expression analysis and differentiation experiments have cast doubt on the potential and validity of neurosphere-derived cells for cell therapy [29-32]. Furthermore, evidence suggests that not only NSCs but more differentiated progeny can also generate neurospheres in vitro. Ablation of rapidly dividing cells from the SEZ by treatment of mice with antimitotic drugs such as cytosine arabinoside (AraC) results in a reduction in neurosphere-forming cells isolated in EGF-containing medium [31]. This was interpreted to indicate that a significant proportion of the EGF-responsive spherogenic cells are TAPs. However, although there may be some foundation to this interpretation of the anti-mitotic paradigm, the experiments may also be biased. It has been suggested that a feedback mechanism to the NSC from its progeny may also regulate stem cell status (see later).

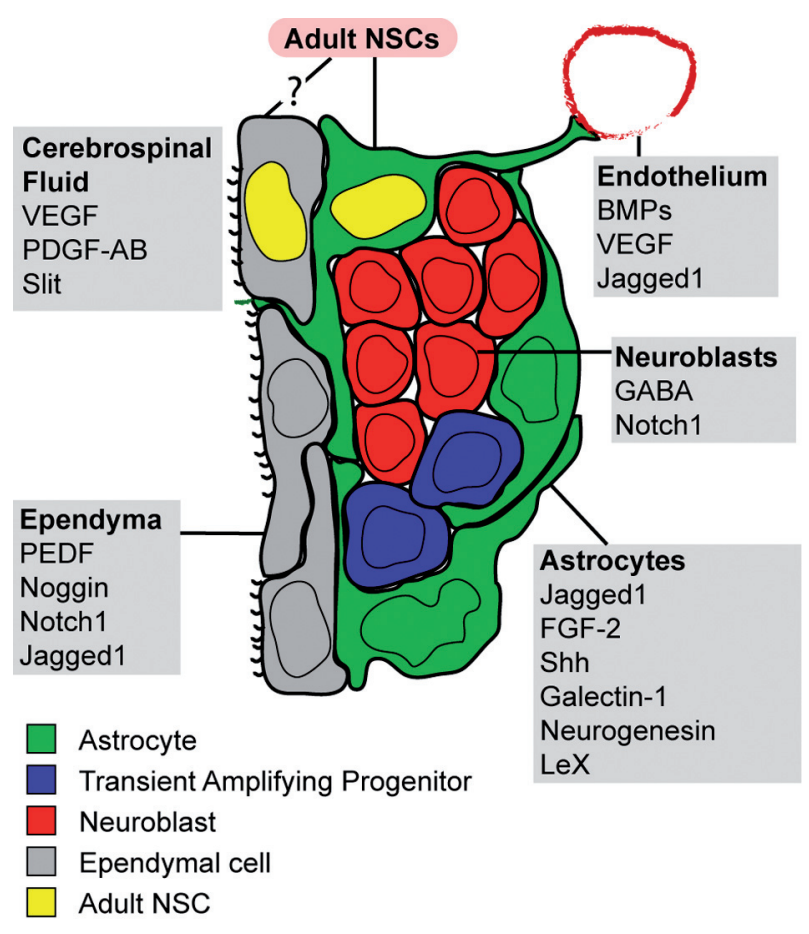

Figure 1. The adult neurogenic niche. The adult mammalian subependymal zone is composed of four principle cell types: Astrocytes (green cells) are resident support cells and accumulating evidence indicates that they include aNSCs. Ependymal cells (grey) line the wall of the ventricles and some might have NSC-like features. aNSCs rarely divide and give-rise to transient amplifying progenitors (blue) which, following a definite number of divisions, generate neuroblasts (red) that are destined for the olfactory bulb. Some of the astrocytes contact the endothelial cells, suggesting that aNSCs might be in direct contact with the circulatory system. The factors implicated in the control of the aNSC fate choices are listed in the grey boxes together with the cell type that presents them.

Thus, in the situation where the SEZ degenerates and the progeny of the NSC, TAPs and neuroblasts, are reduced due to anti-mitotic drug treatment, NSCs may be promoted to enter the cell cycle precociously to compensate, thus rendering them more susceptible to AraC than would have been predicted. Hence, NSCs could also be killed by the anti-mitotic treatment which would also result in a reduction in spherogenic cells. The lack of definitive markers again prevents the conclusive dissemination of the results. More detailed analysis is required to establish if neural progenitors that have a short cell cycle (TAPs) are able to form neurospheres from a nonlesioned forebrain. Clearly, the estimated number of non-NSC derived neurospheres indicates that very few TAPs (the major mitotic population in the SEZ) are spherogenic. In the future, it will be interesting to establish if these putative non-NSC spherogenic cells may be an intermediate between committed TAPs and NSC. Alternatively, spherogenic TAPs may belong to the relatively minor oligodendroglia progenitor population in the SEZ. Although the source 


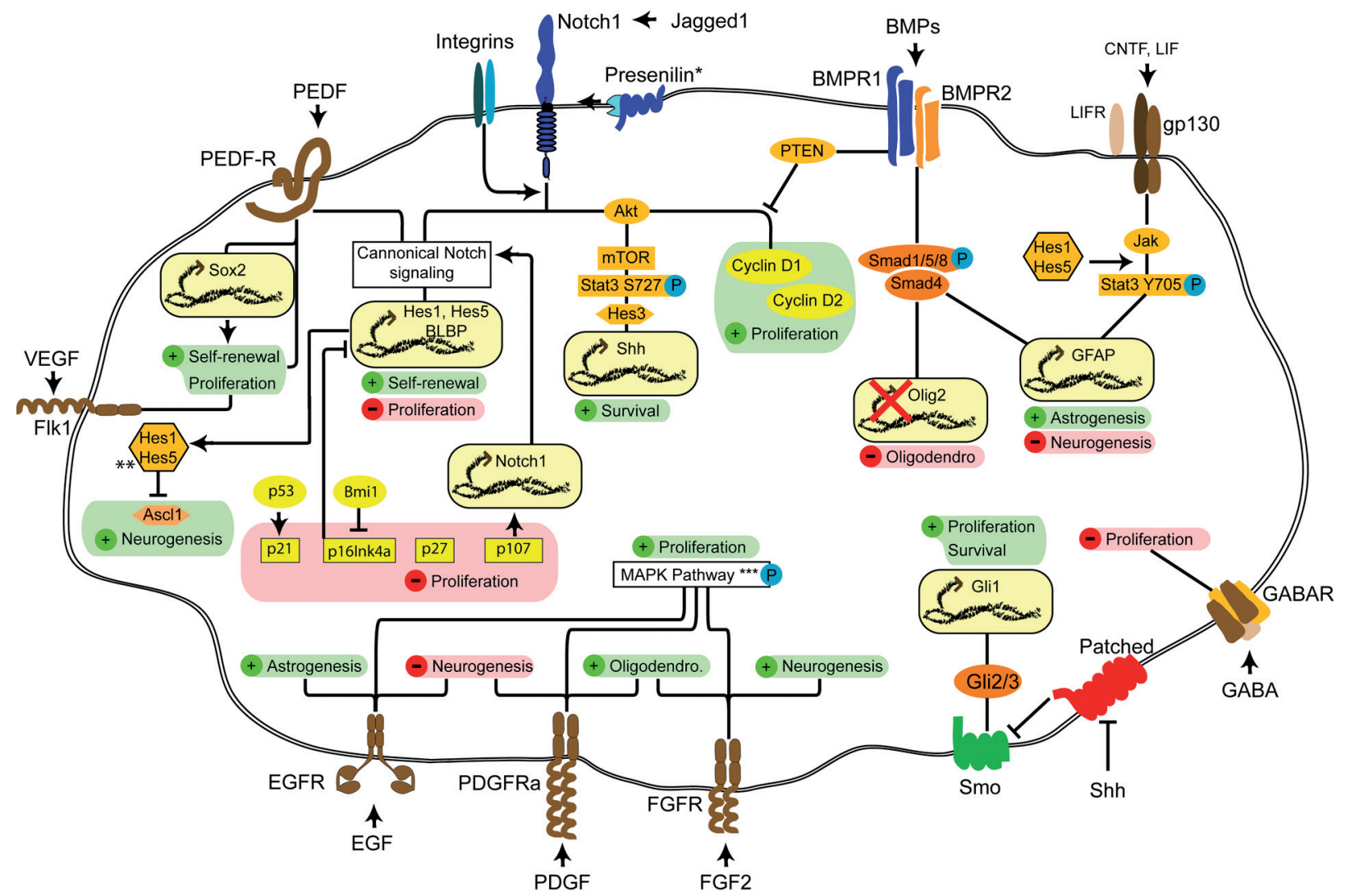

Figure 2. Interplay between multiple signaling pathways controls the fate of aNSCs. A complex net of signaling pathways influences the fate of aNSCs by affecting their proliferation, self-renewal, choice of lineage differentiation and survival. The interplay between the pathways and intrinsic regulator is complex, and among the vast intracellular interactions only those suggested to play a role in the control of the aNSC fate are shown. Cell extrinsic cues and the receptors they activate, intracellular components (connected with lines), the signal is either positive (+, green background) or negative (-, red background) for the given fate. Arrows indicate induction and discontinued lines indicate inhibition of the respective process. Oligodendro. : Oligodendrogenesis. Smo: Smoothened. *: Presenilins are the enzymatic subunit of the gamma-secretase complex. **: The roles of Hes1 and Hes5 as effectors of Notch signaling are well studied during embryonic neurogenesis; however, these are not conclusively shown in adult neurogenesis. ***: MAPK signaling is activated by multiple growth factor receptors, but not necessarily the means through which all the pleiotrophic effects are exerted. Further analysis is required for correct annotation of the downstream elements of receptor tyrosine kinases in aNSCs.

of spherogenic cells isolated from the adult brain and their relationship to NSCs in vivo remains unclear, they may still be of clinical use. However, there is also an obvious lack of in vivo models to address the full differentiation potential of in vitro expanded spherogenic cells in a stem cell assay comparable to the reconstitution and serial transplantation assay that has been used so successfully in the hematopoietic system [29].

\section{Adult neural stem cells}

The identification and isolation of adult human NSCs that generate neurons in vitro were milestones in regenerative medicine [9, 33-37]. Explant cultures established from epileptic patients provided the first data that the adult human brain, like that of rodents, contains neural progenitors that generate neurons in vitro [33, 34]. Analysis of post-mortem brains of carcinoma patients treated with bromodeoxyuridine (BrdU), which is incorporated into the genome of the proliferating cells, provided the first evidence of newborn neurons in the human brain [9]. Selfrenewing and multipotent human NSCs were cultured soon after $[36,37]$. Due to the inability to genetically manipulate human NSCs in vivo, the majority of the data remains descriptive but provocative, and whether there is indeed continuous neurogenesis in humans is still under debate [38, 39]. Thus, the majority of the information relating to human aNSCs stems from rodents. Hence, although amenable for genetic and experimental manipulation to address function and potential, the relationship of rodent cells to putative human aNSCs that may be useful for therapy remains vague and must be viewed critically. 
Table 1. Identifying adult NSCs. The list of markers used to identify NSCs in the adult mouse SVZ. Marker (left column) indicates the name of the protein or, in the case of LeX and CD133, glycoepitopes. Features (middle column) include a recapitulation of the expression pattern of each marker and the respective references.

\begin{tabular}{|c|c|c|}
\hline Marker & Features & References \\
\hline \multirow[t]{2}{*}{ GFAP } & Expressed by SEZ and SGZ astrocytes in rodents, primates and the human. & \\
\hline & Not expressed by TAPs and neuroblasts. & {$[16,40]$} \\
\hline Gli1 & $\begin{array}{l}\text { Marker of Shh activity, is expressed by astrocytes as well as } \\
\text { neural progenitors in the SEZ and SGZ. }\end{array}$ & {$[103,104]$} \\
\hline Notch1 & $\begin{array}{l}\text { Expressed by SEZ astrocytes, ependyma, neuroblasts } \\
\text { and a lineage-population. }\end{array}$ & {$[68,137,138]$} \\
\hline Sox1, Sox2, Nestin & $\begin{array}{l}\text { General markers of neural progenitors and possibly ependyma. } \\
\text { A single Sox } 2+\text { cell in the SGZ can generate neurons and astrocytes }\end{array}$ & {$[41-44,46,48,53]$} \\
\hline Musahi1 & $\begin{array}{l}\text { An mRNA binding protein implicated in regulation of Notch signalling, is } \\
\text { expressed by neural progenitors of the adult mammalian brain. }\end{array}$ & {$[46-48]$} \\
\hline LeX & $\begin{array}{l}\text { A secreted carbohydrate, expressed by neural progenitors and SEZ } \\
\text { astrocytes, which include all the sphere forming cells. }\end{array}$ & {$[63,166]$} \\
\hline CD133 & Expressed by ependymal cells. A glyco modification of Prominin-1 & {$[51,52]$} \\
\hline PDGF-R & $\begin{array}{l}\text { Expressed by a population which can give-rise to both neurons and } \\
\text { oligodendrocytes in the adult mouse SEZ. }\end{array}$ & {$[85]$} \\
\hline FGF-R & Expressed by SEZ astrocytes, the putative FGF responsive spherogenic cells. & {$[82-84]$} \\
\hline Tlx & An orphan nuclear protein expressed by SGZ and SEZ progenitors. & {$[154-156]$} \\
\hline
\end{tabular}

Table 2. Signaling in the NSC niche. The niche signals that have been implicated in the control of the cell fate choices of aNSCs are listed. Factors (left column) indicate secreted molecules or signaling pathways of the aNSC niche. Features (middle column) include a recapitulation of the role of each signaling molecule/pathway in the control of adult NSCs and the respective references.

\begin{tabular}{|c|c|c|}
\hline Factors & Features & References \\
\hline FGF-2 & $\begin{array}{l}\text { One of the mitogens used to culture NSCs in vitro. } \\
\text { Promotes oligodendrogenesis and neurogenesis. }\end{array}$ & {$[28,29,82-84,86]$} \\
\hline PDGF-AB & Promotes oligodendrogenesis and inhibits neurogenesis. & {$[85,86]$} \\
\hline Notch signaling & $\begin{array}{l}\text { Required for the maintanance of NSCs in vitro. } \\
\text { Promotes astrogenesis at the expense of neurogenesis during postnatal } \\
\text { development and in the adult SGZ. } \\
\text { May be required for the survival of NSCs. }\end{array}$ & {$[68,129,134-138]$} \\
\hline BMP signaling & $\begin{array}{l}\text { Induces astrogliogenesis, inhibition is required for proper neurogenesis. } \\
\text { Low levels may also be required for neuronal differentiation at the expense } \\
\text { of oligodendrogenesis. }\end{array}$ & {$[62,87-89,90-93,97]$} \\
\hline gp130 signaling & $\begin{array}{l}\text { Promotes astrogliogenesis at the expense of neurogenesis. } \\
\text { LIF induced signalling induces NSC self-renewal. }\end{array}$ & {$[95-98]$} \\
\hline EGF & $\begin{array}{l}\text { One of the mitogens used to culture NSCs in vitro. } \\
\text { Induces cell migration and astrogliogenesis at the expense of neurogenesis. }\end{array}$ & {$[6,7,27,29,82-84,86]$} \\
\hline VEGF & Promotes NSC expansion and enhances neurogenesis & {$[105,108]$} \\
\hline GABA & $\begin{array}{l}\text { May act on SEZ and SGZ astrocytes as a feedback loop to inhibit } \\
\text { neurogenesis. }\end{array}$ & {$[110-114]$} \\
\hline PEDF & Induces NSC self-renewal via activation of Notch signaling and Sox2. & [76] \\
\hline Neurogenesin & Induces neurogenesis via inhibition of BMP signaling & [91] \\
\hline Shh signaling & Induces NSC self-renewal and proliferation & {$[100-104]$} \\
\hline
\end{tabular}

\section{Astrocytes as stem cells}

The prevailing evidence accumulated since the mid1990s indicates that aNSCs in rodents belong to astrocytic lineages. SEZ astrocytes and some neurogenic NSCs are labeled in transgenic mice expressing reporter proteins from regulatory elements of the human intermediate filament Glial Fibrillary Acidic Protein ( $g f a p$ ) gene $[16,40]$. In addition, SEZ GFAP+ cells are quiescent and many survive anti-mitotic drug treatment. They rapidly enter the cell cycle upon withdrawal of the anti-mitotic drug supporting their 
function as neurogenic progenitors in the regenerating SEZ [16]. Expression analysis and transgenic reporter mice indicate that neural progenitor cells, including some GFAP + astrocytes in the adult SEZ, express the Sry-related HMG group transcription factors Sox1, Sox 2 and regulatory elements of the rat Nestin gene [41-44]. Furthermore, inducible Cre-mediated lineage tracing of astrocyte-specific L-glutamate/L-aspartate transporter (GLAST) or Nestin expressing cells indicate that these populations are neurogenic and self-renewing in vivo [45]. In addition, some SEZ astrocytes express the receptors for FGF and platelet derived growth factor (PDGF), mitogens that affect neurogenesis in vivo and expand spherogenic cells in vitro (see below).

Comparisons show that we know even less about the identity of the human aNSCs. As described above, the human SEZ includes a population of GFAP+ astrocytes, which might include NSCs. Similar to rodents, Sox 2 and Musashi1 are expressed in the human SEZ as well as by neurosphere cells derived from the human brain [46-48]. Antigen-based cell sorting of human brain tissue and subsequent analysis in culture suggests that NSCs in both fetal and adult human brains are included in a CD133+ CD34- CD45fraction [49]. It is interesting that CD133, a glycoepitope expressed on the multi-pass membrane protein Prominin1, is also expressed by polarized radial progenitors in the embryonic mouse neural tube, where it is localized to the apical membrane [50]. In the adult mouse SEZ the situation is less clear, with conflicting reports claiming CD133 expression, which is mainly confined to the ependymal cell layer, by aNSCs in vivo [51,52].

\section{The ependymal controversy}

Although it is clear that SEZ astrocytes include aNSCs, in 1999 Johannson et al. reported that multiciliated ependymal cells of the lateral ventricle walls overlying the SEZ generate NSC-like cells in vitro [37]. As ependymal cells are, under normal circumstances, mitotically inactive, these findings were criticised and rejected by most in the field. However, the flame of neurogenic ependymal cells has been rekindled by a number of reports also claiming to show neurogenesis from ependymal cells $[51,53]$. At the protein level, cells within the ependymal layer express progenitor markers including Sox 2 and Nestin and the ependyma is highly positive for the stem cell associated marker CD133. Using transgenic approaches, new findings support that cells in the ependyma generate neurons in vivo and can behave like aNSCs [51, 53]. Furthermore, the transgenic approaches using the regulatory elements of the human gfap gene do not clarify the situation, as the ependyma expresses GFAP at low levels together with another astrocytic protein $S 100 \beta$ [16]. One tangible and plausible explanation for the finding that cells in the ependymal layer can generate neurons could be the presence of astrocytes in the ependymal sheet. Indeed, SEZ astrocytes are found interdigitated between ependymal cells and their numbers seem to increase with age $[54,55]$. It is unclear whether these astrocytes play a role in ependymal maintenance replacing cells in the adult but aNSCs and ependymal cells have common ancestors in the radial progenitors spanning from the ventricle through the striatum during early postnatal development [56, 57]. It is plausible that SEZ astrocytes within the ependymal layer retain the potential to generate ependymal cells as well as contributing to neurogenesis. Thus, these new findings and reports of ependymal neurogenesis make the identity of the aNSC less clear. However, it remains possible that, under certain conditions including lesion and isolation for cell culture, ependymal cells or their progenitors are able to divide and may become neurogenic. It must be noted that, even the AraC experiments and regeneration of the SEZ does not clarify the question as, being postmitotic, ependymal cells survive the anti-mitotic drug treatment. Lineage tracing experiments provide the strongest evidence for the presence of ependymal aNSCs, but rely on the specificity of the Nestin, FoxJ1 and Prominin1 promoters used and must be critically evaluated [51, 53]. "Clean" genetic lineage-tracing experiments will be needed in the future.

\section{The neurogenic niche and its factors}

As neurogenesis is detectable mainly in two evolutionarily conserved regions of the adult mammalian brain, the SEZ and the dentate gyrus $[2,11,58]$, these brain regions must contain a functional neurogenic microenvironment which also maintains NSCs in an undifferentiated and potent state [26, 59]. The cues that control the fate of the NSCs are provided by specialized support cells and the extracellular matrix of the germinal layers, which together likely form the NSC niche during adult neurogenesis [26, 59-63]. Astrocytes form a structural part of the adult neurogenic niche and express molecules implicated in adult neurogenesis in vivo [15, 64-68]. Cultured astrocytes from specific regions of the developing and adult brain can induce neurogenesis from neural progenitors in vitro [61, 69-71]. Furthermore, microglia and endothelial cells likely contribute to the niche as they can enhance neurogenesis in vitro [63, 72-75]. Similarly, 
ependymal cells express several genes involved in the generation of a permissive environment for neurogenesis and NSC maintenance [62, 68, 76].

Several extrinsic factors provided by the niche are implicated in the control of maintenance and differentiation of NSCs as well as their early progeny. Irrespective of their spatial origin, transplanted NSCs can integrate throughout the SEZ and retain neurogenic potential, suggesting that the niche maintenance signals are constant $[77,78]$. On the other hand, it has been reported that adult NSCs located at distinct positions in the SEZ have a restricted potential to give-rise-to specific interneuron subtypes in the olfactory bulb [78]. The restricted neurogenic potential of NSCs is independent of environmental cues, suggesting that intrinsic factors control their potential to generate specific neuronal subtypes [78]. The spatial pattern and fate restriction is claimed to be established during embryonic development [79]. In addition, the type of interneurons generated is dependent on the temporal origin of the NSC, suggesting that either NSCs or the niche could be constantly changing [80, 81]. Elucidating the molecular factors that underlie the patterning of NSCs might have important implication for clinical applications that aim to generate specific types of neurons and might lead to deviations from the original description of a stem cell that can generate any cell in the adult brain.

\section{Signaling within the aNSC niche}

Classically, EGF and FGF2 have been used to isolate and expand aNSC-like cells. Although their roles in vivo remain unclear, intra-ventricular infusion of these factors into mice has a pronounced effect on neurogenesis. In contrast to claims that a common progenitor responds in vitro to both EGFand FGF2, in vivo these factors have very different effects [82, 83]. EGF induces a marked proliferation of GFAP + cells in the SEZ, which is normally not seen in the neurogenic zone, and their infiltration into the surrounding tissue as a hyperplastic mass. This increase in proliferation is associated with a reduction in neurogenesis, suggesting that EGF-responsive cells, which generate neurons under normal conditions, are stimulated by EGF to proliferate and give-rise to astrocytes. In contrast, FGF2-infusion into the lateral ventricles results in an expansion of neuroblasts and increased neurogenesis in the SEZ. In addition, FGF2 induces migration of progenitors to the olfactory bulb. Thus, rather than increasing NSC expansion as may have been predicted from the neurosphere assay, exogenous FGF2 does not result in expansion of SEZ astrocytes in vivo in the way EGF does. The effect of
FGF in vivo could be interpreted as an increase in neuronal differentiation. A similar effect has been seen following FGF2 treatment of embryo-derived NSCs, which proliferate in response to high levels of FGF2 in vitro but undergo neurogenesis when exposed to reduced FGF2 concentrations [82-84].

PDGF has also been shown to be a mitogen for spherogenic NSCs isolated from the adult mouse brain, however, only in combination with FGF2 and not EGF [85]. PDGF-receptors on SEZ cells are phosphorylated in vivo, suggesting that signaling is active in the adult neurogenic forebrain. In contrast to FGF, but similar to EGF, PDGF infusion into the lateral ventricles of adult mice results in activation of SEZ astrocytes, hyperplasias and gliogenesis at the expense of neurogenesis $[85,86]$. Due to the effects of PDGFs to reduce neurogenesis, neurogenic NSCs must respond to activation of the pathway, although an indirect mechanism cannot be ruled out.

Bone morphogenic protein (BMP) signaling has been shown to affect neurogenesis both in vitro and in vivo by increasing astrocyte formation at the expense of neurogenesis [62, 87-89]. Over expression of BMP7 in the adult brain results in decreased proliferation and a reduction in neuroblast production, while Noggin, a soluble antagonist of BMP signaling expressed by the ependymal cells of the adult SEZ, promotes neurogenesis [62,89].

BMPs act as morphogens through activation of the transcriptional regulators Smads but can also activate phosphatase and tensin homologue (PTEN) to inhibit cell cycle progression of neural progenitors [90]. Neurogenesin1, a factor secreted by the astrocytes, can promote neurogenesis through the inhibition of BMP signaling [91]. Although these gain-of-function experiments indicate that BMP counteracts neurogenesis, constitutive activation of BMP-receptor1a does not affect neuronal differentiation [87, 92]. In contrast to BMPs reported role in blocking neurogenesis and activating gliogenesis in the brain, genetic loss of Smad4 function revealed a role in suppressing oligodendrogenesis through down-regulation of the transcriptional regulator Olig2 [93]. Smad4 is a central component of the BMP pathway and conditional knockout mice surprisingly showed reduced neurogenesis in the SEZ [93]. These seemingly contradictory results remain to be clarified but dose-dependent effects of BMPs could be at work in the different paradigms. It should be noted that Smad4 is also a downstream component of the tumor growth factorbeta (TGF-beta) signaling, which promotes cell cycle arrest in various tissues [94]. Conditional inactivation of TGF-beta receptor-2, however, did not result in neurogenic defects [93]. 
Possible crosstalk between BMP signaling and other pathways could mediate alternative cell-fate choices made by aNSCs. Interleukin-6 (IL-6) family cytokines (IL-6, IL-11, Ciliary neurotrophic factor (CNTF), leukemia inhibitory factor (LIF), Oncostatin M, Cardiotrophin) activate gp130-mediated Stat signaling to synergize with BMP and induce astrogenesis in vitro [95-97]. Consistently, Smad and Stat are suggested to form a complex with p300 [97]. Interestingly, LIF over expression in the adult brain results in increased self-renewal of NSCs and inhibits neurogenesis [98].

Adult SEZ astrocytes, like most cells, have primary cilia [99]. Ablation of Kif3a, a central component of the kinesis II motor complex, inhibits the function of primary cilia and affects aNSC numbers in the dentate gyrus [100]. In addition, NSCs require functional primary cilia during development, and disruption results in disturbed neural tube development with phenotypes similar to mutations in the Sonic Hedgehog (Shh) pathway [100, 101]. Primary cilia are required for Shh signaling and the key receptor components of the Hedgehog pathway accumulate in primary cilia [102]. Shh has been strongly implicated in adult neurogenesis and as a maintenance signal for NSCs [103]. Shh activates expression of its downstream target and effecter Gli1. Consistent with the single cell RT-PCR data, analysis of Gli1-lacZ transgenic mice indicates that $\mathrm{Shh}$ signaling is active in SEZ astrocytes, TAPs and neuroblasts [103, 104]. Lineage tracing of Gli1+ cells indicated that the population includes NSCs in the SEZ [104]. Systemic administration of the Shh inhibitor cyclopamine results in decreased proliferation in the SEZ in vivo and a decrease in spherogenic cells [103].

Vascular endothelial growth factor (VEGF) is essential for angiogenesis and hematopoiesis through its cognate receptors Flt1 and Flk1 [105-107]. VEGF is produced by endothelial cells and in the brain by the choroid plexus. Flk1 is expressed in the adult brain germinal zones and VEGF has been proposed to play a role as a growth factor for NSCs during development and in the adult brain. VEGF enhances, and blocking Flk1 activity reduces NSC expansion in vitro, and infusion of VEGF into the lateral ventricles of rats increases neurogenesis potentially by acting as a trophic survival factor for neural progenitors [108]. The survival effect of VEGF on NSCs is also seen during embryonic development and may reflect the close interplay between angiogenesis and neurogenesis [74, 109]. Similarly, pigment epitheliumderived factor (PEDF) is secreted by the ependymal and endothelial cells of the SEZ and specifically promotes NSC self-renewal in vivo and in vitro without affecting proliferation [76]. The effects seem to be specific for SEZ astrocytes and not for TAPs and neuroblasts, although genetic analysis is required. The mechanism by which PEDF acts in the SEZ is unclear, but activation of Notch signaling and the increase in the Notch targets Hes1 and Hes5 as well as Sox2 might be partially responsible [76].

Recent data suggest that not only do resident cells in adult germinal zones regulate NSC activity, but a feedback mechanism may also be active. Gammaaminobutyric acid (GABA) joined the pallet of factors regulating the NSC and as a putative niche component. The GABAergic system can control the rate of adult neurogenesis modulating the proliferation of neural progenitors. Although predominantly know as an inhibitory neurotransmitter through activation of chloride channels, neural progenitors in the SEZ with high levels of intracellular chloride can be depolarized by tonic non-synaptic GABA activation [110-113]. Indeed, SEZ astrocytes express GABA receptors and increase proliferation in response to GABA inhibition, suggesting a role in the control of NSC activation [114]. The source remains unclear, but neuroblasts potentially secrete GABA. Thus, the GABA response could be a negative feedback to the progenitors regulating aNSC proliferation and differentiation.

Dopamine is another neurotransmitter implicated in the control of adult neural progenitor proliferation in the SEZ. The primary target of the dopaminergic afferents in the SEZ are TAPs, which express the D2type dopamine receptors and proliferate in response to dopamine stimulation [115, 116]. Consistently, experimental ablation of dopaminergic afferents results in reduced SEZ proliferation which is mainly attributable to TAPs [115, 117, 118]. Interestingly, recent evidence suggests that the dopamine induced increase in cell proliferation and neurogenesis in the adult SEZ is dependent on CNTF [119]. While dopamine signaling has been suggested to inhibit stem cell proliferation, whether aNSCs respond directly to dopamine signals needs to be elucidated. The expression of dopamine receptors by SEZ NSCs has not been convincingly demonstrated $[115,120]$.

The basal lamina is in contact with all cells in the neurogenic niche, and the extracellular matrix (ECM) might be involved in the control of the NSC fate, mainly through the control of mitogenic stimuli [72, 121]. Heparin and chondroitin sulphate proteogylcans, Collagen-1, LewisX (LeX) and Tenascin-C are abundantly expressed in adult neurogenic niches [63, $72,77,122-125]$. Tenascin-C is expressed by SEZ astrocytes and suggested to mark the border of the neurogenic niche $[122,125]$. The proteoglycan LeX is secreted by SEZ astrocytes and is a putative marker of NSCs in vivo and in vitro. LeX might promote NSC proliferation by direct interaction with $\mathrm{FGF} 2$ and 
Wnt1 to present the mitogens to neural progenitors $[63,126]$. Indeed, several components of the Wnt signaling pathway are expressed in the SEZ and SGZ of the adult mice $[127,128]$. Although the role of the canonical Wnt signaling in the adult SEZ is unknown, Wnt1-mediated $\beta$-catenin signaling is implicated in the induction of neurogenesis in the SGZ. Whether NSCs directly respond to Wnt signaling is not clear [128]. Furthermore, integrin activity regulates neurogenesis at multiple levels, from synergizing with Notch in NSCs and regulating proliferation and differentiation [129], to chain migration of neuroblasts in the RMS [123]. The interplay between the basement membrane, ECM and growth factors in the niche may play an important role in fine-tuning neurogenesis.

\section{Notch and lateral signaling during adult neurogenesis}

Although the role of Notch signaling to block neurogenesis and maintain undifferentiated progenitors during development has been addressed, the role of Notch signaling in adult neurogenesis remains unknown. Notch signaling requires a complex proteolytic activation process, the final and critical step of which involves a Presenilin (PS) containing gammasecretase [130]. PS1-mutant mice die in utero with a phenotype similar to that observed for Notch signaling mutants [131-133]. However, $\mathrm{PS}^{+/-}$mice survive to adulthood but show a decreased neurogenesis in the SEZ and a reduction in spherogenic cells [134, 135]. Similarly, pharmacological inhibition of PS-activity results in reduced proliferation and increased cell death in SEZ-derived progenitors [136]. However, the cell autonomous role of PS in NSCs has not been demonstrated convincingly, as a reduction in gammasecretase activity could lead to developmental defects or altered niche activity. During development, PS are required to maintain proper neurogenesis, similar to Notch [134]. However, PS and gamma-secretases have dozens of targets in addition to Notchs, thus it cannot be excluded that the effect of reducing PS on neurogenesis is indeed restricted to its action on Notch signaling.

Components of the Notch signaling pathway including Notch1, Jagged1 and the downstream target Hes5 are expressed in the adult SEZ, suggesting that, as in the embryo, Notch may play a role in adult neurogenesis [137, 138]. Conditional inactivation of Notch1 from adult-derived NSCs results in a complete loss of selfrenewal and stem cell character without any apparent cell death or change in lineage potential [68]. The putative ligand for Notch1 in the adult neurogenic niche is Jagged1, which is also required for NSC maintenance and can replace mitogens to promote
NSCs self-renewal and maintenance in vitro and in vivo [68]. Jagged 1 is expressed by ependymal cells and SEZ astrocytes and might provide the maintenance signal to Notch expressing NSCs. In agreement, Notch1 and Jagged1 double-hemizygous mice show defects in postnatal neurogenesis [68], and activation of Notch signaling via soluble ligand infusion into the ventricles results in enhanced proliferation [136].

Despite effects on the spherogenic cell population and proliferation, it is still unresolved whether Notch signaling acts directly at the level of NSCs. Genetic analysis of mutant mice is required to address the function of Notch signaling and, indeed, which Notch receptors are involved in adult SEZ neurogenesis. Notch signaling via a non-canonical pathway through activation of a Stat3-mTOR pathway in the SEZ activates Shh expression to increase progenitor cells survival in a non cell-autonomous way [136]. Consistent with this, the pro-survival effects of Notch activation can be mimicked by expression of activated Stat3 or Hes3 [136].

\section{Intrinsic control of NSCs and neurogenesis}

NSCs are a rare population in the adult neurogenic SEZ making up a minor fraction of the proliferating cells, but they display unique cell cycle features [139]. Retroviral birth-dating in adult mice revealed that putative NSCs divide slowly, with an average cell cycle time of over 15 days, which has been proposed to allow them to retain their potential throughout life [7]. Their progeny, TAPs, divide multiple times with an estimated cell cycle time of 12 hours and are the majority of the dividing cells in the SEZ. The major progeny of the TAPs, neuroblasts, retain a similar proliferative capacity but gradually become postmitotic during migration en route to the olfactory bulb. The differences in cell cycle kinetics have been exploited to preferentially label specific cell populations using nucleoside analogue administration and markers of cell cycle progression.

BrdU is a thymidine analogue incorporated into newly replicated DNA and is frequently used to label proliferating cells and their progeny. BrdU is relatively short-lived in vivo, being excreted within a few hours after i.p. administration. Thus, a brief exposure to BrdU, single injection or $<24$ hours per os, labels fast dividing cells in the SEZ, whereas NSCs are rarely labeled. On the other hand, prolonged exposure (>>24 hours) of animals to BrdU results in labeling of NSCs which, due to their long cell cycle, should retain the label over an extended period of time [140, 141]. Although label-retaining cells include putative NSCs, the evidence to date is indirect and the func- 
tional data are still lacking [142]. In addition, markers of proliferation such as proliferating cell nuclear antigen (PCNA) and Ki67 are frequently used to label cells within the cell cycle; however, their association with NSCs has not been demonstrated, partially due to the lack of markers. Mcm2, an essential component of the origin of replication complex, is expressed by adult neural progenitors as well as label retaining cells and might play a role in actively cycling NSCs [143]. However, the current theories on the NSC are based on a single population of cells that are continuously in the cell cycle and have homogenous kinetics. Although this simplifies the interpretation of labeling experiments, in reality NSCs may be a dynamic cell population that can leave and enter the cell cycle and respond to local environmental cues. For instance, a mitotically active aNSC could undergo a few rounds of division before falling into a mitotically inactive state, while an inactive aNSC could contribute to brain regeneration by transiting into an active state. In addition, it is slowly becoming clear that the SEZ contains multiple populations of NSCs and it needs to be clarified whether these different populations may have distinct cell cycle characteristics [78]. It remains a major question whether all NSCs in the adult brain are active and contribute to neurogenesis throughout life or whether some become exhausted and are replaced or replenished by a potentially mitotically inactive NSC population.

Genetic analysis has revealed roles for specific genes involved in the intrinsic regulation of the cell cycle of adult neural progenitor populations, including NSCs. However, caution is needed in evaluating the data concerning the cell cycle of aNSCs due to the absence of definitive markers and in vivo assays. Cyclin genes promote progression through the cell cycle in cooperation with the cyclin-dependent kinases (CDKs), an activity regulated by CDK inhibitors (CDKIs). In the absence of the $G_{1}$-specific cyclin $D_{2}$, but not cyclin $D_{1}$, proliferation ceases and neurogenesis in the SEZ fails, indicating that neural progenitors are either not established or fail to be replenished in cyclin $D_{2}$ mutants [144].

On the other hand, the phosphatase PTEN decreases levels of cyclin $\mathrm{D}_{1}$ through inhibition of AKT and might contribute to the long cell cycle time of adult SEZ NSCs by restricting G1-S transition [145-147]. In parallel, retinoblastoma gene family members $(\mathrm{Rb}$, p107, p130) are well-known for their role in inhibiting cell cycle progression by binding to E2F family members [148]. In the absence of p107, mice display an increase in label-retaining cells in the SEZ, which correlates with an elevation in the number of spherogenic cells [149]. This strongly suggests an increase in
aNSC in p107 mutant mice. Roles of Rb and p130 in adult neurogenesis remain elusive, while during embryogenesis $\mathrm{Rb}$ is up-regulated upon initiation of differentiation and p130 is expressed in most-mitotic neurons [150,151]. In addition, Rb mutant mice display a general deficit in the embryonic progenitor cell pool with no apparent NSC phenotype [149]. Thus, $\mathrm{Rb}$ family members seem to have distinct, nonredundant functions in the regulation of adult neurogenesis.

In support of a connection between the cell cycle progression and regulation of progenitor cell fate choices, mutants of several cyclin dependent kinase inhibitors (CDKI) display striking defects in adult neurogenesis. Evidence suggests that $\mathrm{p} 21^{\text {cip } 1 / \text { waf1 }}$ promotes a more quiescent state and, in its absence, NSCs initially expand beyond wild type levels but are eventually exhausted [141]. An up-stream factor of $\mathrm{p} 21^{\text {cip1/waf1 }}$, the tumor suppressor protein $\mathrm{p} 53$, is also implicated in promoting quiescence of adult NSCs [152]. In addition, genetic data support a role of p $27^{\text {Kip1 }}$ in the inhibition of neural progenitor proliferation, although the phenotype can be attributed at least partially to an effect on TAPs [153]. Proliferation of SGZ and SEZ progenitors requires the orphan nuclear receptor Tlx, which is implicated in the inhibition of $\mathrm{p} 21^{\mathrm{cip} 1 / \text { waf1 }}$ but not $\mathrm{p} 27^{\mathrm{Kip} 1}$, further confirming differential functions of specific cell cycle regulators [154-156]. Tlx functions, at least partially, by recruiting histone deacetylases, stressing the importance of epigenetic regulation in the control of NSC maintenance [157]. In agreement, the polycomb family repressor Bmi1 is required for postnatal maintenance of NSCs [158]. Once again connecting cell cycle regulation to other cell fate regulators, increased levels of the tumor suppressor $\mathrm{p} 16^{\mathrm{Ink} 4 \mathrm{a}}$ in Bmi1deficient mice lead to reduced self-renewal and depletion of NSCs early in postnatal life, mimicking its function during ageing $[159,160]$. Multiple pathways converge on the regulators of the cell cycle progression which might represent key switches governing NSC fate choices.

\section{Crosstalk between cell cycle components and extracellular signals}

It is tempting to speculate that specific molecular components that control cell cycle progression in neural progenitors might be directly associated with the factors that govern NSC self-renewal, longevity and differentiation potential. This is elaborated in neural progenitors, where $\mathrm{p} 107$ binds to the promoter and elevates the expression of Notchl resulting in increased Notch activity in adult derived neuro- 
spheres in vitro [149]. Activation of Notch signaling in the adult spinal cord in response to injury induces proliferation linking environmental signals to cell cycle progression [161]. In muscle stem cells (MSCs), Notch signaling is also implicated in the control of CDKI expression. It inhibits the expression of $\mathrm{p} 15^{\text {Ink4b }}$, $\mathrm{p} 16^{\text {Ink4a }}, \mathrm{p} 21^{\text {cip1/waf1 }}$ and $\mathrm{p} 27^{\text {Kip1 } 1}$ induced by the inhibition of TGF $\beta$-dependent Smad3 activity [162]. In contrast to embryonic neurogenesis, decreased levels of Notch signaling in MSCs of aged mice leads to a loss of proliferative and regenerative capacity rather than precocious differentiation [163]. In a reciprocal pathway, $\mathrm{p} 16^{\text {Ink4a }}$ has been implicated in the inhibition of Hes1, a target of Notch signaling [164]. It will be interesting to further investigate the role of Notch signaling and other pathways in the regulation of the NSC cell cycle.

\section{Conclusions and perspectives}

NSCs persist in the adult mammalian brain throughout life and generate functional neurons. The proliferation and differentiation of the neural progenitors is governed by multiple signaling mechanisms provided by the specialized microenvironment of the niche. The striking regenerative capacity of NSCs raises hopes for therapy for multiple degenerative disorders including stroke, Parkinson's, Huntington's and Alzheimer's disease. Correct generation and manipulation of specific neuronal subtypes require extensive understanding of the identity of different neural progenitor populations and the signals that govern their fate. Although the presence of NSCs is accepted, whether a single population of aNSCs exist in vivo, or multiple functionally distinct populations constitute the endogenous pool remains to be substantiated. It is, however, of critical importance to elucidate the lineage potential of NSCs using in vivo experimental paradigms.

1 Guillemot, F. (2007) Cell fate specification in the mammalian telencephalon. Prog. Neurobiol. 83, 37-52.

2 Altman, J. (1962) Are new neurons formed in the brains of adult mammals? Science 135, 1127-1128.

3 Altman, J. and Das, G. D. (1965) Autoradiographic and histological evidence of postnatal hippocampal neurogenesis in rats. J. Comp. Neurol. 124, 319-335.

4 Goldman, S. A. and Nottebohm, F. (1983) Neuronal production, migration, and differentiation in a vocal control nucleus of the adult female canary brain. Proc. Natl. Acad. Sci. USA 80, 2390-2394.

5 Nottebohm, F., Alvarez-Buylla, A., Cynx, J., Kirn, J., Ling, C. Y., Nottebohm, M., Suter, R., Tolles, A. and Williams, H. (1990) Song learning in birds: the relation between perception and production. Philos. Trans. R. Soc. Lond. B. Biol. Sci. 329, $115-124$.

6 Reynolds, B. A. and Weiss, S. (1992) Generation of neurons and astrocytes from isolated cells of the adult mammalian central nervous system. Science 255, 1707-1710.
7 Morshead, C. M., Reynolds, B. A., Craig, C. G., McBurney, M. W., Staines, W. A., Morassutti, D., Weiss, S. and van der Kooy, D. (1994) Neural stem cells in the adult mammalian forebrain: a relatively quiescent subpopulation of subependymal cells. Neuron 13, 1071-1082.

8 Bernier, P. J., Bedard, A., Vinet, J., Levesque, M. and Parent, A. (2002) Newly generated neurons in the amygdala and adjoining cortex of adult primates. Proc. Natl. Acad. Sci. USA 99, 11464-11469.

9 Eriksson, P. S., Perfilieva, E., Bjork-Eriksson, T., Alborn, A. M., Nordborg, C., Peterson, D. A. and Gage, F. H. (1998) Neurogenesis in the adult human hippocampus. Nat. Med. 4, 1313-1317.

10 Kilpatrick, T. J. and Bartlett, P. F. (1993) Cloning and growth of multipotential neural precursors: requirements for proliferation and differentiation. Neuron 10, 255-265.

11 Luskin, M. B. (1993) Restricted proliferation and migration of postnatally generated neurons derived from the forebrain subventricular zone. Neuron 11, 173-189.

12 Menn, B., Garcia-Verdugo, J. M., Yaschine, C., GonzalezPerez, O., Rowitch, D. and Alvarez-Buylla, A. (2006) Origin of oligodendrocytes in the subventricular zone of the adult brain. J. Neurosci. 26, 7907-7918.

13 Lois, C. and Alvarez-Buylla, A. (1994) Long-distance neuronal migration in the adult mammalian brain. Science 264, $1145-1148$.

14 Biebl, M., Cooper, C. M., Winkler, J. and Kuhn, H. G. (2000) Analysis of neurogenesis and programmed cell death reveals a self-renewing capacity in the adult rat brain. Neurosci. Lett. 291, 17-20.

15 Doetsch, F., Garcia-Verdugo, J. M. and Alvarez-Buylla, A. (1997) Cellular composition and three-dimensional organization of the subventricular germinal zone in the adult mammalian brain. J. Neurosci. 17, 5046-5061.

16 Doetsch, F., Caille, I., Lim, D. A., Garcia-Verdugo, J. M. and Alvarez-Buylla, A. (1999) Subventricular zone astrocytes are neural stem cells in the adult mammalian brain. Cell 97, 703716.

17 Sawamoto, K., Wichterle, H., Gonzalez-Perez, O., Cholfin, J. A., Yamada, M., Spassky, N., Murcia, N. S., Garcia-Verdugo, J. M., Marin, O., Rubenstein, J. L., Tessier-Lavigne, M., Okano, H. and Alvarez-Buylla, A. (2006) New neurons follow the flow of cerebrospinal fluid in the adult brain. Science 311, $629-632$.

18 Sanai, N., Tramontin, A. D., Quinones-Hinojosa, A., Barbaro, N. M., Gupta, N., Kunwar, S., Lawton, M. T., McDermott, M. W., Parsa, A. T., Manuel-Garcia Verdugo, J., Berger, M. S. and Alvarez-Buylla, A. (2004) Unique astrocyte ribbon in adult human brain contains neural stem cells but lacks chain migration. Nature 427, 740-744.

19 Rodriguez-Perez, L. M., Perez-Martin, M., Jimenez, A. J. and Fernandez-Llebrez, P. (2003) Immunocytochemical characterisation of the wall of the bovine lateral ventricle. Cell Tissue Res. 314, 325-335.

20 Quinones-Hinojosa, A., Sanai, N., Soriano-Navarro, M., Gonzalez-Perez, O., Mirzadeh, Z., Gil-Perotin, S., RomeroRodriguez, R., Berger, M. S., Garcia-Verdugo, J. M. and Alvarez-Buylla, A. (2006) Cellular composition and cytoarchitecture of the adult human subventricular zone: a niche of neural stem cells. J. Comp. Neurol. 494, 415-434.

21 Nunes, M. C., Roy, N. S., Keyoung, H. M., Goodman, R. R., McKhann, G., 2nd, Jiang, L., Kang, J., Nedergaard, M. and Goldman, S. A. (2003) Identification and isolation of multipotential neural progenitor cells from the subcortical white matter of the adult human brain. Nat. Med. 9, 439-447.

22 Curtis, M. A., Kam, M., Nannmark, U., Anderson, M. F., Axell, M. Z., Wikkelso, C., Holtas, S., van Roon-Mom, W. M., Bjork-Eriksson, T., Nordborg, C., Frisen, J., Dragunow, M., Faull, R. L. and Eriksson, P. S. (2007) Human neuroblasts migrate to the olfactory bulb via a lateral ventricular extension. Science 315, 1243-1249. 
23 Seri, B., Garcia-Verdugo, J. M., McEwen, B. S. and AlvarezBuylla, A. (2001) Astrocytes give rise to new neurons in the adult mammalian hippocampus. J. Neurosci. 21, 7153-7160.

24 Kempermann, G., Jessberger, S., Steiner, B. and Kronenberg, G. (2004) Milestones of neuronal development in the adult hippocampus. Trends Neurosci. 27, 447-452.

25 Suh, H., Consiglio, A., Ray, J., Sawai, T., D’Amour, K. A. and Gage, F. H. (2007) In Vivo Fate Analysis Reveals the Multipotent and Self-Renewal Capacities of Sox2 $(+)$ Neural Stem Cells in the Adult Hippocampus. Cell Stem Cell 1, 515528.

26 Gage, F. H. (2000) Mammalian neural stem cells. Science 287, $1433-1438$.

27 Reynolds, B. A., Tetzlaff, W. and Weiss, S. (1992) A multipotent EGF-responsive striatal embryonic progenitor cell produces neurons and astrocytes. J. Neurosci. 12, 4565-4574.

28 Gritti, A., Parati, E. A., Cova, L., Frolichsthal, P., Galli, R. Wanke, E., Faravelli, L., Morassutti, D. J., Roisen, F., Nickel, D. D. and Vescovi, A. L. (1996) Multipotential stem cells from the adult mouse brain proliferate and self-renew in response to basic fibroblast growth factor. J. Neurosci. 16, 1091-1100.

29 Reynolds, B. A. and Rietze, R. L. (2005) Neural stem cells and neurospheres-re-evaluating the relationship. Nat. Methods 2, $333-336$.

30 Seaberg, R. M. and van der Kooy, D. (2002) Adult rodent neurogenic regions: the ventricular subependyma contains neural stem cells, but the dentate gyrus contains restricted progenitors. J. Neurosci. 22, 1784-1793.

31 Doetsch, F., Petreanu, L., Caille, I., Garcia-Verdugo, J. M. and Alvarez-Buylla, A. (2002) EGF converts transit-amplifying neurogenic precursors in the adult brain into multipotent stem cells. Neuron 36, 1021-1034.

32 Galli, R., Gritti, A., Bonfanti, L. and Vescovi, A. L. (2003) Neural stem cells: an overview. Circ. Res. 92, 598-608.

33 Kirschenbaum, B., Nedergaard, M., Preuss, A., Barami, K. Fraser, R. A. and Goldman, S. A. (1994) In vitro neuronal production and differentiation by precursor cells derived from the adult human forebrain. Cereb. Cortex 4, 576-589.

34 Pincus, D. W., Harrison-Restelli, C., Barry, J., Goodman, R. R., Fraser, R. A., Nedergaard, M. and Goldman, S. A. (1997) In vitro neurogenesis by adult human epileptic temporal neocortex. Clin. Neurosurg. 44, 17-25.

35 Kornack, D. R. and Rakic, P. (1999) Continuation of neurogenesis in the hippocampus of the adult macaque monkey. Proc. Natl. Acad. Sci. USA 96, 5768-5773.

36 Kukekov, V. G., Laywell, E. D., Suslov, O., Davies, K., Scheffler, B., Thomas, L. B., O'Brien, T. F., Kusakabe, M. and Steindler, D. A. (1999) Multipotent stem/progenitor cells with similar properties arise from two neurogenic regions of adult human brain. Exp. Neurol. 156, 333-344.

37 Johansson, C. B., Momma, S., Clarke, D.L., Risling, M., Lendahl, U. and Frisen, J. (1999) Identification of a neural stem cell in the adult mammalian central nervous system. Cell $96,25-34$

38 Kornack, D. R. and Rakic, P. (2001) Cell proliferation without neurogenesis in adult primate neocortex. Science 294, 2127 2130

39 Seress, L., Abraham, H., Tornoczky, T. and Kosztolanyi, G. (2001) Cell formation in the human hippocampal formation from mid-gestation to the late postnatal period. Neuroscience $105,831-843$

40 Morshead, C. M., Garcia, A. D., Sofroniew, M. V. and van Der Kooy, D. (2003) The ablation of glial fibrillary acidic protein positive cells from the adult central nervous system results in the loss of forebrain neural stem cells but not retinal stem cells. Eur. J. Neurosci. 18, 76-84.

41 Brazel, C. Y., Limke, T. L., Osborne, J. K., Miura, T., Cai, J., Pevny, L. and Rao, M. S. (2005) Sox2 expression defines a heterogeneous population of neurosphere-forming cells in the adult murine brain. Aging Cell 4, 197-207.

42 Ellis, P., Fagan, B. M., Magness, S. T., Hutton, S., Taranova, O., Hayashi, S., McMahon, A., Rao, M. and Pevny, L. (2004)
SOX2, a persistent marker for multipotential neural stem cells derived from embryonic stem cells, the embryo or the adult. Dev. Neurosci. 26, 148-165.

43 Barraud, P., Thompson, L., Kirik, D., Bjorklund, A. and Parmar, M. (2005) Isolation and characterization of neural precursor cells from the Sox1-GFP reporter mouse. Eur. J. Neurosci. 22, 1555-1569.

44 Kawaguchi, A., Miyata, T., Sawamoto, K., Takashita, N., Murayama, A., Akamatsu, W., Ogawa, M., Okabe, M., Tano, Y., Goldman, S. A. and Okano, H. (2001) Nestin-EGFP transgenic mice: visualization of the self-renewal and multipotency of CNS stem cells. Mol. Cell. Neurosci. 17, 259-273.

45 Mori, T., Tanaka, K., Buffo, A., Wurst, W., Kuhn, R. and Gotz, M. (2006) Inducible gene deletion in astroglia and radial glia-a valuable tool for functional and lineage analysis. Glia $54,21-34$.

46 Schwartz, P. H., Bryant, P. J., Fuja, T. J., Su, H., O’Dowd, D. K. and Klassen, H. (2003) Isolation and characterization of neural progenitor cells from post-mortem human cortex. J. Neurosci. Res. 74, 838-851.

47 Kaneko, Y., Sakakibara, S., Imai, T., Suzuki, A., Nakamura, Y., Sawamoto, K., Ogawa, Y., Toyama, Y., Miyata, T. and Okano, H. (2000) Musashi1: an evolutionally conserved marker for CNS progenitor cells including neural stem cells. Dev. Neurosci. 22, 139-153.

48 Pincus, D. W., Keyoung, H. M., Harrison-Restelli, C., Goodman, R. R., Fraser, R. A., Edgar, M., Sakakibara, S., Okano, H., Nedergaard, M. and Goldman, S. A. (1998) Fibroblast growth factor-2/brain-derived neurotrophic factor-associated maturation of new neurons generated from adult human subependymal cells. Ann. Neurol. 43, 576-585.

49 Uchida, N., Buck, D. W., He, D., Reitsma, M. J., Masek, M., Phan, T. V., Tsukamoto, A. S., Gage, F. H. and Weissman, I. L. (2000) Direct isolation of human central nervous system stem cells. Proc. Natl. Acad. Sci. USA 97, 14720-14725.

50 Dubreuil, V., Marzesco, A. M., Corbeil, D., Huttner, W. B. and Wilsch-Brauninger, M. (2007) Midbody and primary cilium of neural progenitors release extracellular membrane particles enriched in the stem cell marker prominin-1. J. Cell Biol. 176, 483-495.

51 Coskun, V., Wu, H., Blanchi, B., Tsao, S., Kim, K., Zhao, J., Biancotti, J. C., Hutnick, L., Krueger, R. C., Jr., Fan, G., de Vellis, J. and Sun, Y. E. (2008) CD133+ neural stem cells in the ependyma of mammalian postnatal forebrain. Proc. Natl. Acad. Sci. USA 105, 1026-1031.

52 Pfenninger, C. V., Roschupkina, T., Hertwig, F., Kottwitz, D., Englund, E., Bengzon, J., Jacobsen, S. E. and Nuber, U. A. (2007) CD133 is not present on neurogenic astrocytes in the adult subventricular zone, but on embryonic neural stem cells, ependymal cells, and glioblastoma cells. Cancer Res. 67, $5727-5736$

53 Meletis, K., Barnabe-Heider, F., Carlen, M., Evergren, E., Tomilin, N., Shupliakov, O. and Frisen, J. (2008) Spinal cord injury reveals multilineage differentiation of ependymal cells. PLoS Biol. 6, e182.

54 Luo, J., Daniels, S. B., Lennington, J. B., Notti, R. Q. and Conover, J. C. (2006) The aging neurogenic subventricular zone. Aging Cell 5, 139-152.

55 Luo, J., Shook, B. A., Daniels, S. B. and Conover, J. C. (2008) Subventricular zone-mediated ependyma repair in the adult mammalian brain. J. Neurosci. 28, 3804-3813.

56 Merkle, F. T., Tramontin, A. D., Garcia-Verdugo, J. M. and Alvarez-Buylla, A. (2004) Radial glia give rise to adult neural stem cells in the subventricular zone. Proc. Natl. Acad. Sci. USA 101, 17528-17532.

57 Spassky, N., Merkle, F. T., Flames, N., Tramontin, A. D., Garcia-Verdugo, J. M. and Alvarez-Buylla, A. (2005) Adult ependymal cells are postmitotic and are derived from radial glial cells during embryogenesis. J. Neurosci. 25, 10-18.

58 Kuhn, H. G., Dickinson-Anson, H. and Gage, F. H. (1996) Neurogenesis in the dentate gyrus of the adult rat: age-related 
decrease of neuronal progenitor proliferation. J. Neurosci. 16, $2027-2033$

59 Alvarez-Buylla, A. and Lim, D. A. (2004) For the long run: maintaining germinal niches in the adult brain. Neuron 41, 683-686.

60 Palmer, T. D., Willhoite, A. R. and Gage, F. H. (2000) Vascular niche for adult hippocampal neurogenesis. J. Comp. Neurol. 425, 479-494.

61 Song, H., Stevens, C. F. and Gage, F. H. (2002) Astroglia induce neurogenesis from adult neural stem cells. Nature 417, 39-44.

62 Lim, D. A., Tramontin, A. D., Trevejo, J. M., Herrera, D. G., Garcia-Verdugo, J. M. and Alvarez-Buylla, A. (2000) Noggin antagonizes BMP signaling to create a niche for adult neurogenesis. Neuron 28, 713-726.

63 Capela, A. and Temple, S. (2002) LeX/ssea-1 is expressed by adult mouse CNS stem cells, identifying them as nonependymal. Neuron 35, 865-875.

64 Lafon-Cazal, M., Adjali, O., Galeotti, N., Poncet, J., Jouin, P., Homburger, V., Bockaert, J. and Marin, P. (2003) Proteomic analysis of astrocytic secretion in the mouse. Comparison with the cerebrospinal fluid proteome. J. Biol. Chem. 278, 2443824448.

65 Seri, B., Garcia-Verdugo, J. M., Collado-Morente, L., McEwen, B. S. and Alvarez-Buylla, A. (2004) Cell types, lineage, and architecture of the germinal zone in the adult dentate gyrus. J. Comp. Neurol. 478, 359-378.

66 Taupin, P., Ray, J., Fischer, W. H., Suhr, S. T., Hakansson, K., Grubb, A. and Gage, F. H. (2000) FGF-2-responsive neural stem cell proliferation requires $\mathrm{CCg}$, a novel autocrine/ paracrine cofactor. Neuron 28, 385-397.

67 Shetty, A. K., Hattiangady, B. and Shetty, G. A. (2005) Stem/ progenitor cell proliferation factors FGF-2, IGF-1, and VEGF exhibit early decline during the course of aging in the hippocampus: role of astrocytes. Glia 51, 173-186.

68 Nyfeler, Y., Kirch, R. D., Mantei, N., Leone, D. P., Radtke, F., Suter, U. and Taylor, V. (2005) Jagged1 signals in the postnatal subventricular zone are required for neural stem cell selfrenewal. Embo J. 24, 3504-3515.

69 Lim, D. A. and Alvarez-Buylla, A. (1999) Interaction between astrocytes and adult subventricular zone precursors stimulates neurogenesis. Proc. Natl. Acad. Sci. USA 96, 7526-7531.

70 Toda, H., Takahashi, J., Mizoguchi, A., Koyano, K. and Hashimoto, N. (2000) Neurons generated from adult rat hippocampal stem cells form functional glutamatergic and GABAergic synapses in vitro. Exp. Neurol. 165, 66-76.

71 Song, H. J., Stevens, C. F. and Gage, F. H. (2002) Neural stem cells from adult hippocampus develop essential properties of functional CNS neurons. Nat. Neurosci. 5, 438-445.

72 Mercier, F., Kitasako, J. T. and Hatton, G. I. (2002) Anatomy of the brain neurogenic zones revisited: fractones and the fibroblast/macrophage network. J. Comp. Neurol. 451, 170188.

73 Palmer, T. D. (2002) Adult neurogenesis and the vascular Nietzsche. Neuron 34, 856-858.

74 Shen, Q., Goderie, S. K., Jin, L., Karanth, N., Sun, Y., Abramova, N., Vincent, P., Pumiglia, K. and Temple, S. (2004) Endothelial cells stimulate self-renewal and expand neurogenesis of neural stem cells. Science 304, 1338-1340.

75 Walton, N. M., Sutter, B. M., Laywell, E. D., Levkoff, L. H., Kearns, S. M., Marshall, G. P., 2nd, Scheffler, B. and Steindler, D.A. (2006) Microglia instruct subventricular zone neurogenesis. Glia 54, 815-825.

76 Ramirez-Castillejo, C., Sanchez-Sanchez, F., Andreu-Agullo, C., Ferron, S.R., Aroca-Aguilar, J. D., Sanchez, P., Mira, H., Escribano, J. and Farinas, I. (2006) Pigment epitheliumderived factor is a niche signal for neural stem cell renewal. Nat. Neurosci. 9, 331-339.

77 Jankovski, A. and Sotelo, C. (1996) Subventricular zoneolfactory bulb migratory pathway in the adult mouse: cellular composition and specificity as determined by heterochronic and heterotopic transplantation. J. Comp. Neurol. 371, 376396.

78 Merkle, F. T., Mirzadeh, Z. and Alvarez-Buylla, A. (2007) Mosaic organization of neural stem cells in the adult brain. Science 317, 381-384.

79 Young, K. M., Fogarty, M., Kessaris, N. and Richardson, W. D. (2007) Subventricular zone stem cells are heterogeneous with respect to their embryonic origins and neurogenic fates in the adult olfactory bulb. J. Neurosci. 27, 8286-8296.

80 Batista-Brito, R., Close, J., Machold, R. and Fishell, G. (2008) The distinct temporal origins of olfactory bulb interneuron subtypes. J. Neurosci. 28, 3966-3975.

81 De Marchis, S., Bovetti, S., Carletti, B., Hsieh, Y. C., Garzotto, D., Peretto, P., Fasolo, A., Puche, A. C. and Rossi, F. (2007) Generation of distinct types of periglomerular olfactory bulb interneurons during development and in adult mice: implication for intrinsic properties of the subventricular zone progenitor population. J. Neurosci. 27, 657-664.

82 Kuhn, H. G., Winkler, J., Kempermann, G., Thal, L. J. and Gage, F. H. (1997) Epidermal growth factor and fibroblast growth factor-2 have different effects on neural progenitors in the adult rat brain. J. Neurosci. 17, 5820-5829.

83 Craig, C. G., Tropepe, V., Morshead, C. M., Reynolds, B. A., Weiss, S. and van der Kooy, D. (1996) In vivo growth factor expansion of endogenous subependymal neural precursor cell populations in the adult mouse brain. J. Neurosci. 16, 26492658.

84 Gritti, A., Frolichsthal-Schoeller, P., Galli, R., Parati, E. A., Cova, L., Pagano, S. F., Bjornson, C. R. and Vescovi, A. L. (1999) Epidermal and fibroblast growth factors behave as mitogenic regulators for a single multipotent stem cell-like population from the subventricular region of the adult mouse forebrain. J. Neurosci. 19, 3287-3297.

85 Jackson, E. L., Garcia-Verdugo, J. M., Gil-Perotin, S., Roy, M., Quinones-Hinojosa, A., VandenBerg, S. and AlvarezBuylla, A. (2006) PDGFR alpha-positive B cells are neural stem cells in the adult SVZ that form glioma-like growths in response to increased PDGF signaling. Neuron 51, 187-199.

86 Lachapelle, F., Avellana-Adalid, V., Nait-Oumesmar, B. and Baron-Van Evercooren, A. (2002) Fibroblast growth factor-2 (FGF-2) and platelet-derived growth factor AB (PDGF AB) promote adult SVZ-derived oligodendrogenesis in vivo. Mol. Cell. Neurosci. 20, 390-403.

87 Gross, R. E., Mehler, M. F., Mabie, P. C., Zang, Z., Santschi, L. and Kessler, J. A. (1996) Bone morphogenetic proteins promote astroglial lineage commitment by mammalian subventricular zone progenitor cells. Neuron 17, 595-606.

88 Chen, H. L. and Panchision, D. M. (2007) Concise review: bone morphogenetic protein pleiotropism in neural stem cells and their derivatives-alternative pathways, convergent signals. Stem Cells 25, 63-68.

89 Cho, S. R., Benraiss, A., Chmielnicki, E., Samdani, A., Economides, A. and Goldman, S. A. (2007) Induction of neostriatal neurogenesis slows disease progression in a transgenic murine model of Huntington disease. J. Clin. Invest. 117, 2889-2902.

90 Mathieu, C., Sii-Felice, K., Fouchet, P., Etienne, O., Haton, C., Mabondzo, A., Boussin, F. D. and Mouthon, M. A. (2008) Endothelial cell-derived bone mo rphogenetic proteins control proliferation of neural stem/progenitor cells. Mol. Cell. Neurosci. 38, 569-577.

91 Ueki, T., Tanaka, M., Yamashita, K., Mikawa, S., Qiu, Z., Maragakis, N. J., Hevner, R. F., Miura, N., Sugimura, H. and Sato, K. (2003) A novel secretory factor, Neurogenesin-1, provides neurogenic environmental cues for neural stem cells in the adult hippocampus. J. Neurosci. 23, 11732-11740.

92 Coskun, V., Venkatraman, G., Yang, H., Rao, M. S. and Luskin, M. B. (2001) Retroviral manipulation of the expression of bone morphogenetic protein receptor Ia by SVZa progenitor cells leads to changes in their p19(INK4d) expression but not in their neuronal commitment. Int. J. Dev. Neurosci. 19, 219-227. 
93 Colak, D., Mori, T., Brill, M. S., Pfeifer, A., Falk, S., Deng, C. Monteiro, R., Mummery, C., Sommer, L. and Gotz, M. (2008) Adult neurogenesis requires Smad4-mediated bone morphogenic protein signaling in stem cells. J. Neurosci. 28, 434-446.

94 Attisano, L. and Wrana, J. L. (2000) Smads as transcriptional co-modulators. Curr. Opin. Cell Biol. 12, 235-243.

95 Bonni, A., Sun, Y., Nadal-Vicens, M., Bhatt, A., Frank, D. A., Rozovsky, I., Stahl, N., Yancopoulos, G. D. and Greenberg, M. E. (1997) Regulation of gliogenesis in the central nervous system by the JAK-STAT signaling pathway. Science 278, $477-483$

96 Johe, K. K., Hazel, T. G., Muller, T., Dugich-Djordjevic, M. M. and McKay, R. D. (1996) Single factors direct the differentiation of stem cells from the fetal and adult central nervous system. Genes Dev. 10, 3129-3140.

97 Nakashima, K., Yanagisawa, M., Arakawa, H., Kimura, N., Hisatsune, T., Kawabata, M., Miyazono, K. and Taga, T. (1999) Synergistic signaling in fetal brain by STAT3-Smad1 complex bridged by $\mathrm{p} 300$. Science $284,479-482$

98 Bauer, S. and Patterson, P. H. (2006) Leukemia inhibitory factor promotes neural stem cell self-renewal in the adult brain. J. Neurosci. 26, 12089-12099.

99 Tramontin, A. D., Garcia-Verdugo, J. M., Lim, D. A. and Alvarez-Buylla, A. (2003) Postnatal development of radial glia and the ventricular zone (VZ): a continuum of the neural stem cell compartment. Cereb. Cortex 13, 580-587.

100 Han, Y. G., Spassky, N., Romaguera-Ros, M., GarciaVerdugo, J. M., Aguilar, A., Schneider-Maunoury, S. and Alvarez-Buylla, A. (2008) Hedgehog signaling and primary cilia are required for the formation of adult neural stem cells. Nat. Neurosci. 11, 277-284.

101 Alvarez-Buylla, A., Garcia-Verdugo, J. M. and Tramontin, A D. (2001) A unified hypothesis on the lineage of neural stem cells. Nat. Rev. Neurosci. 2, 287-293.

102 Kovacs, J. J., Whalen, E. J., Liu, R., Xiao, K., Kim, J., Chen, M., Wang, J., Chen, W. and Lefkowitz, R. J. (2008) Betaarrestin-mediated localization of smoothened to the primary cilium. Science 320, 1777-1781.

103 Palma, V., Lim, D. A., Dahmane, N., Sanchez, P., Brionne, T. C., Herzberg, C. D., Gitton, Y., Carleton, A., Alvarez-Buylla, A. and Ruiz i Altaba, A. (2005) Sonic hedgehog controls stem cell behavior in the postnatal and adult brain. Development $132,335-344$.

104 Ahn, S. and Joyner, A. L. (2005) In vivo analysis of quiescent adult neural stem cells responding to Sonic hedgehog. Nature 437, 894-897.

105 Shalaby, F., Rossant, J., Yamaguchi, T. P., Gertsenstein, M., Wu, X. F., Breitman, M. L. and Schuh, A. C. (1995) Failure of blood-island formation and vasculogenesis in Flk-1-deficient mice. Nature 376, 62-66.

106 Shalaby, F., Ho, J., Stanford, W. L., Fischer, K. D., Schuh, A C., Schwartz, L., Bernstein, A. and Rossant, J. (1997) A requirement for Flk1 in primitive and definitive hematopoiesis and vasculogenesis. Cell 89, 981-990.

107 Ema, M., Faloon, P., Zhang, W. J., Hirashima, M., Reid, T., Stanford, W. L., Orkin, S., Choi, K. and Rossant, J. (2003) Combinatorial effects of Flk1 and Tal1 on vascular and hematopoietic development in the mouse. Genes Dev. 17, 380-393.

108 Schanzer, A., Wachs, F. P., Wilhelm, D., Acker, T., CooperKuhn, C., Beck, H., Winkler, J., Aigner, L., Plate, K. H. and Kuhn, H. G. (2004) Direct stimulation of adult neural stem cells in vitro and neurogenesis in vivo by vascular endothelial growth factor. Brain. Pathol. 14, 237-248.

109 Wada, T., Haigh, J. J., Ema, M., Hitoshi, S., Chaddah, R., Rossant, J., Nagy, A. and van der Kooy, D. (2006) Vascular endothelial growth factor directly inhibits primitive neura stem cell survival but promotes definitive neural stem cell survival. J. Neurosci. 26, 6803-6812.

110 Owens, D. F. and Kriegstein, A. R. (2002) Is there more to GABA than synaptic inhibition? Nat. Rev. Neurosci. 3, 715727.
111 Tozuka, Y., Fukuda, S., Namba, T., Seki, T. and Hisatsune, T. (2005) GABAergic excitation promotes neuronal differentiation in adult hippocampal progenitor cells. Neuron 47, 803815.

112 Wang, J. M., Johnston, P. B., Ball, B. G. and Brinton, R. D. (2005) The neurosteroid allopregnanolone promotes proliferation of rodent and human neural progenitor cells and regulates cell-cycle gene and protein expression. J. Neurosci. $25,4706-4718$.

113 Ge, S., Goh, E. L., Sailor, K. A., Kitabatake, Y., Ming, G. L. and Song, H. (2006) GABA regulates synaptic integration of newly generated neurons in the adult brain. Nature 439, 589593.

114 Liu, X., Wang, Q., Haydar, T. F. and Bordey, A. (2005) Nonsynaptic GABA signaling in postnatal subventricular zone controls proliferation of GFAP-expressing progenitors. Nat. Neurosci. 8, 1179-1187.

115 Hoglinger, G. U., Rizk, P., Muriel, M. P., Duyckaerts, C., Oertel, W. H., Caille, I. and Hirsch, E. C. (2004) Dopamine depletion impairs precursor cell proliferation in Parkinson disease. Nat. Neurosci. 7, 726-735.

116 Freundlieb, N., Francois, C., Tande, D., Oertel, W. H., Hirsch, E. C. and Hoglinger, G. U. (2006) Dopaminergic substantia nigra neurons project topographically organized to the subventricular zone and stimulate precursor cell proliferation in aged primates. J. Neurosci. 26, 2321-2325.

117 Baker, S. A., Baker, K. A. and Hagg, T. (2004) Dopaminergic nigrostriatal projections regulate neural precursor proliferation in the adult mouse subventricular zone. Eur. J. Neurosci. 20, 575-579.

118 Winner, B., Geyer, M., Couillard-Despres, S., Aigner, R., Bogdahn, U., Aigner, L., Kuhn, G. and Winkler, J. (2006) Striatal deafferentation increases dopaminergic neurogenesis in the adult olfactory bulb. Exp. Neurol. 197, 113-121.

119 Yang, P., Arnold, S. A., Habas, A., Hetman, M. and Hagg, T. (2008) Ciliary neurotrophic factor mediates dopamine D2 receptor-induced CNS neurogenesis in adult mice. J. Neurosci. 28, 2231-2241.

120 Kippin, T. E., Kapur, S. and van der Kooy, D. (2005) Dopamine specifically inhibits forebrain neural stem cell proliferation, suggesting a novel effect of antipsychotic drugs. J. Neurosci. 25, 5815-5823.

121 Doetsch, F. (2003) A niche for adult neural stem cells. Curr. Opin. Genet. Dev. 13, 543-550.

122 Gates, M. A., Thomas, L. B., Howard, E. M., Laywell, E. D., Sajin, B., Faissner, A., Gotz, B., Silver, J. and Steindler, D.A. (1995) Cell and molecular analysis of the developing and adult mouse subventricular zone of the cerebral hemispheres. J. Comp. Neurol. 361, 249-266.

123 Jacques, T. S., Relvas, J. B., Nishimura, S., Pytela, R., Edwards, G. M., Streuli, C. H. and ffrench-Constant, C. (1998) Neural precursor cell chain migration and division are regulated through different beta1 integrins. Development $125,3167-3177$.

124 Murase, S. and Horwitz, A. F. (2002) Deleted in colorectal carcinoma and differentially expressed integrins mediate the directional migration of neural precursors in the rostral migratory stream. J. Neurosci. 22, 3568-3579.

125 Garcion, E., Halilagic, A., Faissner, A. and ffrench-Constant, C. (2004) Generation of an environmental niche for neural stem cell development by the extracellular matrix molecule tenascin C. Development 131, 3423-3432.

126 Capela, A. and Temple, S. (2006) LeX is expressed by principle progenitor cells in the embryonic nervous system, is secreted into their environment and binds Wnt-1. Dev. Biol. 291, 300-313.

127 Morris, D. C., Zhang, Z. G., Wang, Y., Zhang, R. L., Gregg, S., Liu, X. S. and Chopp, M. (2007) Wnt expression in the adult rat subventricular zone after stroke. Neurosci. Lett. 418, 170174.

128 Lie, D. C., Colamarino, S. A., Song, H. J., Desire, L., Mira, H., Consiglio, A., Lein, E. S., Jessberger, S., Lansford, H., Dearie, 
A. R. and Gage, F. H. (2005) Wnt signalling regulates adult hippocampal neurogenesis. Nature 437, 1370-1375.

129 Campos, L. S., Decker, L., Taylor, V. and Skarnes, W. (2006) Notch, epidermal growth factor receptor, and beta1-integrin pathways are coordinated in neural stem cells. J. Biol. Chem. 281, 5300-5309.

130 Mumm, J. S. and Kopan, R. (2000) Notch signaling: from the outside in. Dev. Biol. 228, 151-165.

131 Shen, J., Bronson, R. T., Chen, D. F., Xia, W., Selkoe, D. J. and Tonegawa, S. (1997) Skeletal and CNS defects in Presenilin-1deficient mice. Cell 89, 629-639.

132 Wong, P. C., Zheng, H., Chen, H., Becher, M. W., Sirinathsinghji, D. J., Trumbauer, M. E., Chen, H. Y., Price, D. L., Van der Ploeg, L. H. and Sisodia, S. S. (1997) Presenilin 1 is required for Notch1 and DII1 expression in the paraxial mesoderm. Nature 387, 288-292.

133 de la Pompa, J. L., Wakeham, A., Correia, K. M., Samper, E., Brown, S., Aguilera, R. J., Nakano, T., Honjo, T., Mak, T. W., Rossant, J. and Conlon, R. A. (1997) Conservation of the Notch signalling pathway in mammalian neurogenesis. Development 124, 1139-1148.

134 Hitoshi, S., Tropepe, V., Ekker, M. and van der Kooy, D. (2002) Neural stem cell lineages are regionally specified, but not committed, within distinct compartments of the developing brain. Development 129, 233-244.

135 Alexson, T. O., Hitoshi, S., Coles, B. L., Bernstein, A. and van der Kooy, D. (2006) Notch signaling is required to maintain all neural stem cell populations-irrespective of spatial or temporal niche. Dev. Neurosci. 28, 34-48.

136 Androutsellis-Theotokis, A., Leker, R. R., Soldner, F., Hoeppner, D. J., Ravin, R., Poser, S. W., Rueger, M. A., Bae, S. K., Kittappa, R. and McKay, R. D. (2006) Notch signalling regulates stem cell numbers in vitro and in vivo. Nature 442, 823-826.

137 Stump, G., Durrer, A., Klein, A. L., Lutolf, S., Suter, U. and Taylor, V. (2002) Notch1 and its ligands Delta-like and Jagged are expressed and active in distinct cell populations in the postnatal mouse brain. Mech. Dev. 114, 153-159.

138 Irvin, D. K., Nakano, I., Paucar, A. and Kornblum, H. I. (2004) Patterns of Jagged1, Jagged2, Delta-like 1 and Deltalike 3 expression during late embryonic and postnatal brain development suggest multiple functional roles in progenitors and differentiated cells. J. Neurosci. Res. 75, 330-343.

139 Morshead, C. M. (2004) Adult neural stem cells: attempting to solve the identity crisis. Dev. Neurosci. 26, 93-100.

140 Karpowicz, P., Morshead, C., Kam, A., Jervis, E., Ramunas, J., Cheng, V. and van der Kooy, D. (2005) Support for the immortal strand hypothesis: neural stem cells partition DNA asymmetrically in vitro. J. Cell Biol. 170, 721-732.

141 Kippin, T. E., Martens, D. J. and van der Kooy, D. (2005) p21 loss compromises the relative quiescence of forebrain stem cell proliferation leading to exhaustion of their proliferation capacity. Genes Dev. 19, 756-767.

142 Golmohammadi, M. G., Blackmore, D. G., Large, B., Azari, H., Esfandiary, E., Paxinos, G., Franklin, K. B., Reynolds, B. A. and Rietze, R. L. (2008) Comparative analysis of the frequency and distribution of stem and progenitor cells in the adult mouse brain. Stem Cells 26, 979-987.

143 Maslov, A. Y., Barone, T. A., Plunkett, R. J. and Pruitt, S. C. (2004) Neural stem cell detection, characterization, and agerelated changes in the subventricular zone of mice. J. Neurosci. $24,1726-1733$.

144 Kowalczyk, A., Filipkowski, R. K., Rylski, M., Wilczynski, G. M., Konopacki, F. A., Jaworski, J., Ciemerych, M. A., Sicinski, P. and Kaczmarek, L. (2004) The critical role of cyclin D2 in adult neurogenesis. J. Cell Biol. 167, 209-213.

145 Groszer, M., Erickson, R., Scripture-Adams, D. D., Lesche, R., Trumpp, A., Zack, J. A., Kornblum, H. I., Liu, X. and Wu, H. (2001) Negative regulation of neural stem/progenitor cell proliferation by the Pten tumor suppressor gene in vivo. Science 294, 2186-2189.
146 Radu, A., Neubauer, V., Akagi, T., Hanafusa, H. and Georgescu, M. M. (2003) PTEN induces cell cycle arrest by decreasing the level and nuclear localization of cyclin D1. Mol. Cell. Biol. 23, 6139-6149.

147 Goberdhan, D. C. and Wilson, C. (2003) PTEN: tumour suppressor, multifunctional growth regulator and more. Hum. Mol. Genet. 12 Spec No 2, R239-248.

148 Ang Sun, L.B.S.T.G.R.A.G. (2007) From G0 to S phase: A view of the roles played by the retinoblastoma $(\mathrm{Rb})$ family members in the Rb-E2F pathway. J. Cell. Biochem. 102,14001404.

149 Vanderluit, J. L., Ferguson, K. L., Nikoletopoulou, V., Parker, M., Ruzhynsky, V., Alexson, T., McNamara, S. M., Park, D. S., Rudnicki, M. and Slack, R. S. (2004) p107 regulates neural precursor cells in the mammalian brain. J. Cell Biol. 166, 853863.

150 Jiang, Z., Zacksenhaus, E., Gallie, B. L. and Phillips, R. A. (1997) The retinoblastoma gene family is differentially expressed during embryogenesis. Oncogene 14, 1789-1797.

151 Slack, R. S., El-Bizri, H., Wong, J., Belliveau, D. J. and Miller, F. D. (1998) A Critical Temporal Requirement for the Retinoblastoma Protein Family During Neuronal Determination. J. Cell Biol. 140, 1497-1509.

152 Meletis, K., Wirta, V., Hede, S. M., Nister, M., Lundeberg, J. and Frisen, J. (2006) p53 suppresses the self-renewal of adult neural stem cells. Development 133, 363-369.

153 Doetsch, F., Verdugo, J. M., Caille, I., Alvarez-Buylla, A., Chao, M. V. and Casaccia-Bonnefil, P. (2002) Lack of the cellcycle inhibitor p27Kip1 results in selective increase of transitamplifying cells for adult neurogenesis. J. Neurosci. 22, 22552264.

154 Shi, Y., Chichung Lie, D., Taupin, P., Nakashima, K., Ray, J., Yu, R.T., Gage, F. H. and Evans, R.M. (2004) Expression and function of orphan nuclear receptor TLX in adult neural stem cells. Nature 427, 78-83.

155 Zhang, C. L., Zou, Y., He, W., Gage, F. H. and Evans, R. M. (2008) A role for adult TLX-positive neural stem cells in learning and behaviour. Nature 451, 1004-1007.

156 Liu, H. K., Belz, T., Bock, D., Takacs, A., Wu, H., Lichter, P., Chai, M. and Schutz, G. (2008) The nuclear receptor tailless is required for neurogenesis in the adult subventricular zone. Genes Dev. 22, 2473-2478.

157 Sun, G., Yu, R. T., Evans, R. M. and Shi, Y. (2007) Orphan nuclear receptor TLX recruits histone deacetylases to repress transcription and regulate neural stem cell proliferation. Proc. Natl. Acad. Sci. USA 104, 15282-15287.

158 Molofsky, A. V., Pardal, R., Iwashita, T., Park, I. K., Clarke, M. F. and Morrison, S. J. (2003) Bmi-1 dependence distinguishes neural stem cell self-renewal from progenitor proliferation. Nature 425, 962-967.

159 Molofsky, A. V., He, S., Bydon, M., Morrison, S. J. and Pardal, R. (2005) Bmi-1 promotes neural stem cell self-renewal and neural development but not mouse growth and survival by repressing the p16Ink4a and p19Arf senescence pathways. Genes Dev. 19, 1432-1437.

160 Molofsky, A. V., Slutsky, S. G., Joseph, N. M., He, S., Pardal, R., Krishnamurthy, J., Sharpless, N.E. and Morrison, S.J. (2006) Increasing p16INK4a expression decreases forebrain progenitors and neurogenesis during ageing. Nature 443, 448452.

161 Yamamoto, S., Nagao, M., Sugimori, M., Kosako, H., Nakatomi, H., Yamamoto, N., Takebayashi, H., Nabeshima, Y., Kitamura, T., Weinmaster, G., Nakamura, K. and Nakafuku, M. (2001) Transcription factor expression and Notch-dependent regulation of neural progenitors in the adult rat spinal cord. J. Neurosci. 21, 9814-9823.

162 Carlson, M. E., Hsu, M. and Conboy, I. M. (2008) Imbalance between pSmad 3 and Notch induces CDK inhibitors in old muscle stem cells. Nature 454, 528-532.

163 Conboy, I. M., Conboy, M. J., Smythe, G. M. and Rando, T. A. (2003) Notch-mediated restoration of regenerative potential to aged muscle. Science 302, 1575-1577. 
164 Janzen, V., Forkert, R., Fleming, H. E., Saito, Y., Waring, M T., Dombkowski, D. M., Cheng, T., DePinho, R. A., Sharpless, N. E. and Scadden, D. T. (2006) Stem-cell ageing modified by the cyclin-dependent kinase inhibitor p16INK4a. Nature $443,421-426$.

To access this journal online: http://www.birkhauser.ch/CMLS 